\title{
Manipulation of oocytes and in-vitro fertilization
}

\author{
N. Crozet \\ I.N.R.A., Unité Biologie de la Fécondation, 78352 Jouy-en-Josas, France
}

Keywords: oocyte; maturation; fertilization; ruminants

\section{Introduction}

Since the birth of the first calf from an in-vitro fertilized oocyte (Brackett et al., 1982), in-vitro fertilization has been achieved in two other ruminant species: sheep and goats. Efficient in-vitro techniques as a low-cost source of eggs and early embryos are of considerable value for research purposes and for the development of new biotechnologies of agricultural interest. Production of transgenic offspring requires large numbers of zygotes at the pronuclear stage, for gene injection. Multiplication in vitro of identical embryos can be achieved by using mature, enucleated oocytes from any donor as recipients for nuclei from valuable multicellular-stage embryos. Basic research on early development, as well as research to adapt new biotechnologies are also dependent on the production of large supplies of eggs at specific stages of development.

At present, much demand exists for ruminant oocytes and embryos. Bovine eggs are particularly in demand, but interest in sheep and goats is increasing. Producing mature oocytes and early embryos in vivo by superovulation and insemination is not optimal for research and commercial purposes. Considerable variations exist among ruminant females in their response to the superovulation treatments, and repeated stimulations of a given animal lead to variable results. Furthermore, the moment of ovulation and fertilization cannot be precisely predicted. Spreading of these events over a period of several hours is common in these species. Therefore, at the time of recovery the eggs are not synchronous and their stage cannot be ascertained. Using in-vitro methods for oocyte maturation and fertilization, it is now possible to produce cattle, sheep and goat zygotes. Recent advances in knowledge of final gamete maturation and fertilization have largely contributed to improvement of the techniques of oocyte manipulation and in-vitro fertilization in these species. Ovaries collected at a local slaughterhouse may provide an abundant and economic source of immature oocytes which can be matured and fertilized in vitro. Procedures for sperm capacitation may ensure synchronized sperm-egg penetration and, consequently, the production of zygotes at specific developmental stages.

The purpose of this contribution is to review and summarize the mechanisms involved in gamete maturation and fertilization and how these steps can be achieved in vitro. It is also to discuss the efficiency of the in-vitro procedures which determines their application to the animal industry.

\section{Oocyte maturation}

Mammalian oocytes are arrested at the diplotene stage of the first meiotic division. In response to the preovulatory surge of gonadotrophins, the oocyte undergoes resumption of meiosis characterized by germinal vesicle breakdown (GVBD), chromosome condensation, formation of the first meiotic spindle, expulsion of the first polar body and arrest in metaphase of the second meiotic division (MII). These events are defined as oocyte maturation and lead to an ovulated fertilizable oocyte. In cattle and sheep oocytes GVBD and expulsion of the first polar body occur $8-9 \mathrm{~h}$ and 19-21 h respectively after the LH peak (Dziuk, 1965; Kruip et al., 1983; Hyttel et al., 1986a). 
It is well known that mammalian oocytes removed from their follicular environment are able to undergo spontaneous nuclear maturation in vitro. However, oocytes which reach MII in these conditions are not competent to progress to normal fertilization and further embryonic development (Thibault \& Gérard, 1970; Moor \& Trounson, 1977). Developmental incompetence results mainly from abnormal cytoplasmic maturation. Full physiological maturation of the oocyte is accompanied by marked changes in the pattern of protein synthesis (Warnes et al., 1977). Moreover, indirect evidence suggests that some of the newly synthesized proteins may be involved in the regulation of sperm chromatin decondensation and early development up to the blastocyst stage (Moor \& Gandolfi, 1987). Cytoplasmic maturation is also associated with the reorganization of many organelles (review by Thibault et al., 1987). The redistribution of cortical granules and their alignment beneath the plasma membrane of the oocyte is of great importance. Exocytosis of cortical granules at fertilization induces zona pellucida modification and blocks further penetration by supernumerary spermatozoa. A failure in cortical granule redistribution may prevent exocytosis and result in polyspermy. Granulosa cells play an essential role in promoting full oocyte maturation. The oocyte is coupled to adjacent cumulus cells by junctional complexes (Anderson \& Albertini, 1976) which mediate the transport of nutrients and signal molecules from the follicle cells to the oocyte (Moor \& Cran, 1980). Intercellular coupling persists for 9-12 $\mathrm{h}$ after the initiation of maturation in cattle (Hyttel et al., 1986a) and sheep (Moor \& Cran, 1980), permitting the passage of signal molecules into the maturing oocyte. Steroids may represent one class of such signals. Imbalance in the steroid profile during maturation in the sheep induces an abnormal pattern of protein synthesis and results in nuclear abnormalities at fertilization (Osborn \& Moor, 1983). Expansion of the cumulus which occurs in vitro in response to FSH (Thibault, 1972; Ball et al, 1983 ) is an additional aspect of the maturation process. In ruminants, the expanded cumulus is rapidly lost after ovulation; it is therefore not expected to play a direct role at fertilization. However, the disruption of cumulus-oocyte coupling which is associated with redistribution of cytoplasmic organelles (Szöllösi et al., 1978) is important for full oocyte maturation.

The first successful system of ruminant oocyte maturation in vitro mimicked the in-vivo conditions: explanted follicles with enclosed oocytes were incubated in the presence of gonadotrophins (Moor \& Trounson, 1977). However, in view of technical problems associated with the culture of isolated follicles, efforts have been made to improve the conditions of extrafollicular oocyte maturation. Co-culture of cumulus-oocyte complexes with granulosa cells enhances the developmental capacity of the oocytes; this method, initially proposed for the sheep (Staigmiller \& Moor, 1984), has been extended to cattle (Critser et al., 1986; Xu et al., 1987; Fukui \& Ono, 1989) and goats (V. De Smedt \& A. Martino, unpublished data). The co-culture medium was originally supplemented with FSH, LH and oestradiol- $17 \beta$. This procedure resulted in $55 \%$ of sheep oocytes reaching the blastocyst stage (Staigmiller \& Moor, 1984) and 36-38\% of cattle oocytes developing to morulae or blastocysts (Critser et al., 1986; Lu et al., 1987). However, supplementation of the medium with serum from an oestrous cow was as efficient as hormonal addition in cattle (Lu et al., 1987; Le Guienne et al., 1988); the concentrations of FSH, LH and oestradiol in the serum were probably sufficient to support full maturation. Isolated cumulus-oocyte complexes were also matured in the presence of hormones without granulosa cells but yielded a lower frequency of development to the morulablastocyst stage $1.8 \%$ and $28 \%$ for sheep and cow oocytes, respectively (Staigmiller \& Moor, 1984; Sirard et al, 1988).

The success of the maturation process may be influenced by the selection of oocytes before culture and by factors such as the temperature of incubation. Follicular oocytes are currently obtained from ovaries collected at the slaughterhouse; these provide abundant and inexpensive supplies of oocytes for maturation. However, the follicular population of animals in random stages of the oestrous cycle is heterogeneous and stringent selection of the donor follicles is necessary. Oocytes can also be recovered from hormonally stimulated females at a precise stage of the oestrous cycle. Ovarian stimulation produces relatively homogeneous populations of medium-size, non-atretic follicles convenient for research purposes or when the optimal number of oocytes must be collected 
from a valuable animal. The selection of donor follicles is currently based on morphological criteria. The best rates of maturation and cleavage are obtained with intact and compact cumulus-enclosed oocytes (Younis et al., 1989).

A temperature of $39^{\circ} \mathrm{C}$ is optimal for full maturation of cattle, sheep and goat oocytes (Critser et al., 1986; Cheng et al., 1986; V. De Smedt, personal communication). As demonstrated in the sheep (Moor \& Crosby, 1985) a decrease in temperature may have deleterious effects upon oocyte maturation. The most sensitive stages are GVBD and the transition from metaphase I to anaphase and telophase I.

The time to complete maturation in vitro is slightly different among the three species. Expulsion of the first polar body and MII formation occur within 18-21 h in cattle (Hyttel et al., 1986b), $24 \mathrm{~h}$ in sheep (Moor \& Crosby, 1985; Szöllösi et al., 1988) and $27 \mathrm{~h}$ in goats (V. De Smedt, personal communication).

\section{Sperm capacitation and oocyte fertilization}

Ejaculated mammalian spermatozoa must reside for some time in the female genital tract to acquire the ability to fertilize eggs. During transit they undergo molecular changes, called capacitation. Capacitated spermatozoa can achieve the acrosome reaction and can develop hyperactivated motility, two events necessary for oocyte penetration. The mechanisms of capacitation are poorly understood. Part of the capacitation process involves the removal of sperm-coating materials acquired during epididymal transit and during exposure to the seminal plasma (Piko, 1979). Capacitation is also associated with membrane cholesterol depletion and a decrease in the cholesterol/phospholipids ratio which may in turn, result in increased membrane permeability to $\mathrm{Ca}^{2+}$ (review by Langlais \& Roberts, 1985), Sperm capacitation in vitro was much more difficult to achieve in ruminants than in rodents and man. In large domestic species ejaculated spermatozoa are currently used for in-vitro fertilization, while in rodents spermatozoa are collected from the cauda epididymidis. However, differences exist in the capacitating ability of ejaculated and epididymal spermatozoa, due to the presence of decapacitation factors in the seminal plasma. For example, bovine epididymal spermatozoa can be capacitated in single salt solutions, but ejaculated spermatozoa require complementary agents (First \& Parrish, 1987). Furthermore, the time for sperm capacitation varies amongst species. In ruminants capacitation takes longer than in rodents and man and it is imperative to have culture conditions which maintain sperm survival and motility for several hours.

Various in-vitro systems have been proposed for sperm capacitation in ruminant species. A short exposure to high ionic strength (HIS) medium which may remove coating proteins from the sperm surface has been used for bull spermatozoa (Brackett et al., 1982; Sirard \& Lambert, 1985). Addition of heat-inactivated sheep serum to the culture medium was proposed for ram and goat sperm capacitation (Crozet et al., 1987; and unpublished data). The high capacity binding-protein albumin which is naturally present in serum, follicular and oviducal fluids may contribute to the depletion of cholesterol membrane and may favour sperm capacitation (Langlais et al., 1988). Glycosaminoglycans which are also present in follicular fluid and the genital tract have been proposed as in-vitro capacitating factors for bull spermatozoa (Parrish et al., 1985). Although their role in the capacitation process has not been elucidated, incubation of bovine spermatozoa in the presence of heparin increased sperm $\mathrm{Ca}^{2+}$ uptake (Handrow et al., 1989) and intracellular pH (Parrish et al., 1989). A short treatment with the $\mathrm{Ca}^{2+}$ ionophore $\mathrm{A} 23187$ has also been used for bull and goat sperm capacitation (Hanada, 1985). Each of these procedures led to oocyte fertilization and subsequent embryonic development (Tables $2 \& 4$ ), but it does not necessarily mean that they are very efficient for sperm capacitation. By comparing different systems for bull sperm capacitation (Table 1), Marquant-Le Guienne \& Thibault (1987) found that 5-10\% of naked tubal oocytes and $77-87 \%$ of ovulated oocytes surrounded at least partly by cumulus cells were fertilized. 
They suggested that the spermatozoa not fully capacitated during the preincubation period achieved capacitation in contact with the cumulus cells. The efficiency of a capacitation procedure can be evaluated by the time required for sperm-egg penetration after in-vitro insemination. However, few data exist for the schedule of sperm-egg interaction in the in-vitro systems currently used. Sheep spermatozoa capacitated in the presence of serum for $6 \mathrm{~h}$ undergo the acrosome reaction at the zona surface about $1 \mathrm{~h}$ after insemination; moreover, a decondensing sperm nucleus is present in the ooplasm as early as $2 \mathrm{~h}$ after insemination (Crozet, 1988). In bull spermatozoa capacitated by heparin, the acrosome reaction occurs by $5 \mathrm{~h}$ (Hyttel et al., 1988) and $<40 \%$ of oocytes are fertilized at $8 \mathrm{~h}$ after insemination (Leibfried-Rutledge et al., 1989). Delayed sperm-egg penetration may induce some abnormalities which may impair further development. We recently observed that shortening the time of ram sperm preincubation which led to incomplete capacitation at the moment of insemination and to delayed oocyte penetration may result in a high incidence of polyspermy (Y. Cognie, Y. Guérin, C. Guyader, N. Poulin \& N. Crozet, unpublished data).

Table 1. In-vitro fertilization of ovulated bovine oocytes by spermatozoa capacitated under various conditions (from Marquant-Le Guienne \& Thibault, 1987)

\begin{tabular}{lccc}
\hline & \multicolumn{2}{c}{ No. of oocytes fertilized/no. oocytes (\%) } \\
\cline { 3 - 4 } Sperm source & Capacitation & $\begin{array}{c}\text { Tubal oocytes } \\
\text { without cumulus }\end{array}$ & $\begin{array}{l}\text { Tubal oocytes } \\
\text { with cumulus }\end{array}$ \\
\hline Ejaculate & HIS* & $1 / 20(5)$ & $29 / 36(77)$ \\
Ejaculate & DM $\dagger$ & $1 / 21(5)$ & $7 / 8(87)$ \\
Frozen ejaculate & Heparin & $1 / 10(10)$ & $8 / 10(80)$ \\
\hline
\end{tabular}

*High ionic strength treatment (according to Brackett et al., 1982).

$\dagger$ Minimal medium.

${ }_{4}^{4}$ Heparin treatment (according to Parrish et al, 1985).

The development of in-vitro fertilization as a routine technique in ruminants has also been hampered by variations amongst males and even between ejaculates of a given male. Spermatozoa collected from individual bulls (Brackett et al., 1982; Iritani et al., 1986) and rams (Fukui et al., 1988) largely differ in their ability to fertilize oocytes in vitro. However, some modifications to the culture conditions recently proposed may reduce such variation: increased fertilization rates achievable by individual ejaculates from different rams were obtained by raising the $\mathrm{Ca}^{2+}$ concentration in the fertilization medium (Huneau \& Crozet, 1989) and frozen ejaculates from various bulls were brought up to comparable rates of fertilization by adjusting the heparin concentration (Liebfried-Rutledge et al., 1989). Conversely, heparin at low concentration $(0.05 \mu \mathrm{g} / \mathrm{ml})$ was optimal for discriminating individual bulls and was proposed as a valuable tool for evaluating the in-vivo fertility after artificial insemination (Marquant-Le Guienne et al, 1990).

The incidence of polyspermy is relatively high in vitro compared to the natural conditions and polyspermic eggs are not able to support further development. In vivo a few spermatozoa are present near the oocytes during fertilization (Cummins \& Yanagimachi, 1982) while in vitro the sperm/egg ratio usually ranges between $1 \times 10^{4}$ and $1 \times 10^{6}$. Therefore multiple sperm penetration before complete establishment of the block to polyspermy may occur in vitro. Unfortunately culture conditions which would maintain sperm motility at low dilutions comparable to those in vivo are lacking. As already mentioned, not only sperm concentration but the moment of sperm-egg interaction must also be controlled to reduce the incidence of polyspermy.

The temperature of incubation is a crucial factor: successful fertilization in ruminants cannot be achieved at $37^{\circ} \mathrm{C}$ and a body temperature of $38.5-39^{\circ} \mathrm{C}$ is required (First \& Parrish, 1987). 


\section{Efficiency of the in-vitro maturation and fertilization procedures}

This section is not an exhaustive report of this topic, but rather an attempt to discuss results obtained for ruminants by different methods and leading to embryonic development.

\section{Cattle}

In-vitro fertilization of in-vivo matured oocytes has been achieved with ejaculated spermatozoa capacitated either by high-ionic strength medium or heparin (Table 2). Both the fertilization and early development rates were roughly comparable using these systems. Heparin is now widely used for bull sperm capacitation; it seems to be beneficial mainly for frozen semen (Tables $2 \& 3$ ).

Table 2. In-vitro fertilization of in-vivo matured cattle oocytes

\begin{tabular}{|c|c|c|c|c|c|c|c|}
\hline Reference & $\begin{array}{l}\text { Sperm origin } \\
\text { and } \\
\text { capacitation }\end{array}$ & Oocytes & $\begin{array}{l}\% \text { fert- } \\
\text { ilization }\end{array}$ & $\begin{array}{l}\text { Embryonic } \\
\text { development }\end{array}$ & $\begin{array}{c}\% \\
\text { morulae/ } \\
\text { blastocysts }\end{array}$ & Gestation & $\begin{array}{l}\text { No, of } \\
\text { offspring } \\
\text { born }\end{array}$ \\
\hline \multirow{2}{*}{$\begin{array}{l}\text { Brackett et al. } \\
(1982,1984)\end{array}$} & \multirow{3}{*}{$\begin{array}{l}\text { Ejaculated, } \\
\text { HIS } \\
\text { Ejaculated. } \\
\text { HIS }\end{array}$} & Tubal & $43 \cdot 6$ & \multirow[t]{2}{*}{ In vivo } & - & \multirow[t]{2}{*}{$3 / 9$} & \multirow[t]{2}{*}{3} \\
\hline & & Follicle* & $19 \cdot 7$ & & - & & \\
\hline $\begin{array}{l}\text { Sirard \& Lambert, } \\
(1985) \text {, Sirard et al, } \\
(1985)\end{array}$ & & Follicle* & $29 \cdot 8$ & In vivo & 41 & $7 / 14$ & 6 \\
\hline \multirow{2}{*}{$\begin{array}{l}\text { Leibfried-Rutledge } \\
\text { et al. (1987) }\end{array}$} & \multirow{2}{*}{$\begin{array}{l}\text { Ejaculated. } \\
\text { heparin }\end{array}$} & Follicle* & 57 & \multirow[t]{2}{*}{ In vivo } & 45 & \multirow[t]{2}{*}{$2 / 10$} & \multirow[t]{2}{*}{0} \\
\hline & & Tubal & 32 & & 25 & & \\
\hline $\begin{array}{l}\text { Marquant- } \\
\text { Le Guienne } \\
\text { et al. (1989) }\end{array}$ & $\begin{array}{l}\text { Frozen, } \\
\text { heparin }\end{array}$ & Follicle* & 82 & In vilfo & 33 & - & - \\
\hline
\end{tabular}

*Preovulatory.

+With oviducal cells.

Table 3. In-vitro fertilization of in-vitro matured cattle oocytes

\begin{tabular}{|c|c|c|c|c|c|c|}
\hline Reference & $\begin{array}{c}\text { Sperm origin } \\
\text { and } \\
\text { capacitation }\end{array}$ & $\begin{array}{l}\text { Oocyte } \\
\text { maturation }\end{array}$ & $\begin{array}{l}\% \text { fert- } \\
\text { ilization }\end{array}$ & $\begin{array}{l}\text { Embryonic } \\
\text { development }\end{array}$ & $\begin{array}{c}\% \\
\text { morulae/ } \\
\text { blastocysts }\end{array}$ & Gestation \\
\hline $\begin{array}{l}\text { Critser et al. } \\
\text { (1986) }\end{array}$ & $\begin{array}{l}\text { Frozen, } \\
\text { heparin }\end{array}$ & $\begin{array}{l}\text { Granulosa, } \\
\text { FCS, H }\end{array}$ & $81 \cdot 5$ & In vivo & 36 & $1 / 1$ \\
\hline Xu et al. (1987) & $\begin{array}{l}\text { Ejaculated, } \\
\text { heparin }\end{array}$ & $\begin{array}{l}\text { Granulosa, } \\
\text { ECS }\end{array}$ & 70 & In vivo & 38 & $1 / 2$ \\
\hline Luet al. (1987) & $\begin{array}{l}\text { Frozen, } \\
\text { heparin }\end{array}$ & $\begin{array}{l}\text { Granulosa, } \\
\text { ECS }\end{array}$ & - & In vivo & 60 & $14 / 19$ \\
\hline \multirow[t]{2}{*}{$\begin{array}{l}\text { Fukui \& Ono } \\
(1989)\end{array}$} & $\begin{array}{l}\text { Frozen, } \\
\text { heparin }\end{array}$ & $\begin{array}{l}\text { Granulosa, } \\
\text { FCS }\end{array}$ & 71 & In vitro* & $16 \cdot 5$ & $1 / 3$ \\
\hline & & $\begin{array}{l}\text { Granulosa, } \\
\text { ECS }\end{array}$ & 51 & & $16 \cdot 3$ & \\
\hline $\begin{array}{l}\text { Fayrer-Hosken } \\
\text { et al. (1989) }\end{array}$ & $\begin{array}{l}\text { Frozen. } \\
\text { heparin }\end{array}$ & $\begin{array}{l}\text { COC, FCS, } \\
\mathrm{H}\end{array}$ & $41 \cdot 7$ & & - & $1 / 4$ \\
\hline $\begin{array}{l}\text { Goto et al. } \\
(1989)\end{array}$ & $\begin{array}{l}\text { Epididymal, } \\
\text { frozen, } \\
\text { DM + BSA } \\
+ \text { caffeine }\end{array}$ & $\mathrm{COC}, \mathrm{FCS}$ & 57 & $\begin{array}{l}\text { In vitro } \\
\text { (cumulus) }\end{array}$ & $9-12$ & - \\
\hline $\begin{array}{l}\text { Pavlok et al. } \\
\text { (1989) }\end{array}$ & $\begin{array}{l}\text { Epididymal, } \\
\text { ejaculated, } \\
\text { heparin }\end{array}$ & COC, FCS & $66 \cdot 8$ & $\begin{array}{l}\text { In vivo } \\
\text { (cumulus) }\end{array}$ & 16.5 & $2 / 7$ \\
\hline
\end{tabular}

$\mathrm{ECS}=$ oestrous cow serum; FCS = fetal calf serum; $\mathrm{H}=$ added hormones.

*Oviducal cells. 
The fertilizing ability and developmental competence of oocytes matured under various conditions and fertilized by heparin-treated spermatozoa are summarized in Table 3. Co-culture of cumulus-oocyte complexes with granulosa cells yielded higher rates of fertilization $(70-81 \%)$ than did culture of such complexes alone (41-73\%)

Development to the morula-blastocyst stage of oocytes matured in the presence of granulosa cells and fertilized in vitro ranged between 36 and $60 \%$ in vivo but fell to about $16 \%$ in vitro. This emphasizes the necessity to improve culture conditions for the development in vitro of zygotes up to stages compatible with the transfer into the uterine horns of recipient cows, in view of practical applications. Higher rates of blastulation $(33 \%)$ have now been obtained in vitro from in-vivo matured oocytes fertilized in vitro (Marquant-Le Guienne et al., 1989). These authors also demonstrated that culture on tubal and uterine cells and addition of transforming growth factor- $\beta$ (TGF$\beta$ ) to the co-culture medium in the early stages of blastocyst formation stimulated inner cell mass growth and increased the rates of in-vitro hatching blastocysts up to $62 \%: 11$ out of 17 transferred blastocysts developed to term (C. Thibault, personal communication). Therefore we can expect, in the near future, to get culture systems which support a high rate of development of in-vitro fertilized eggs beyond the morula stage.

Presently, as far as in-vitro matured oocytes are concerned (Table 3), pregnancy rates of $25-100 \%$ have been obtained. The higher rates resulted from cumulus-oocyte complexes matured in vitro in the presence of granulosa cells, fertilized in vitro and reaching the morula-blastocyst stage in vivo. However, due to the low number of transfers reported, it is premature to assess the real efficiency of in-vitro maturation-in-vitro fertilization methods in cattle as attested by full embryonic development.

\section{Sheep}

Two procedures have mainly been used for ram sperm capacitation: (1) storage of fresh semen at room temperature, followed by resuspension for $40 \mathrm{~min}$ in medium containing sheep serum; (2) incubation of washed ejaculated spermatozoa for $6 \mathrm{~h}$, at $39 \mathrm{C}$, in the presence of sheep serum (Table 4). Although the percentage of fertilized oocytes was about $80 \%$ in both systems, higher rates of cleavage of in-vitro matured oocytes were obtained with procedure (2) than with procedure (1) $(62.6 \%$ versus $27 \%)$. Using the second method for sperm capacitation, the developmental competence of in-vitro matured oocytes was identical to that of ovulated oocytes (Table 4).

Table 4. In-vitro fertilization of in-vivo or in-vitro matured sheep oocytes

\begin{tabular}{|c|c|c|c|c|c|c|c|}
\hline Reference & $\begin{array}{l}\text { Sperm origin } \\
\text { and } \\
\text { capacitation }\end{array}$ & $\begin{array}{c}\text { Oocyte } \\
\text { maturation }\end{array}$ & $\begin{array}{l}\% \text { fert- } \\
\text { ilization }\end{array}$ & $\begin{array}{c}\% \\
\text { cleaved egg } \\
(2-8 \text { cells })\end{array}$ & $\begin{array}{l}\text { Embryonic } \\
\text { development }\end{array}$ & $\begin{array}{c}\% \\
\text { morulae/ } \\
\text { blastocysts }\end{array}$ & Gestation \\
\hline $\begin{array}{l}\text { Cheng } \\
\text { et al. (1986), } \\
\text { Cheng (1985) }\end{array}$ & Ejaculated (1) & Granulosa, H & 80 & $27 \cdot 4$ & - & - & 7) 16 \\
\hline $\begin{array}{l}\text { Crozet } \\
\text { et al. (1987) }\end{array}$ & Ejaculated (2) & Granulosa, $\mathrm{H}$ & 83 & $62 \cdot 6$ & In vivo & 53 & $4 / 7$ \\
\hline $\begin{array}{l}\text { Fukui } \\
\text { el al. (1988) }\end{array}$ & Ejaculated (1) & Granulosa, H & - & - & In vivo & 35 & - \\
\hline $\begin{array}{l}\text { Crozet } \\
\text { et al. (1987) }\end{array}$ & Ejaculated (2) & Ovulated & $88 \cdot 8$ & $75 \cdot 8$ & In vivo & $52 \cdot 3$ & $4 / 9$ \\
\hline $\begin{array}{l}\text { Cognié } \\
\text { et al. (1990) }\end{array}$ & Ejaculated (2) & Ovulated & $82 \cdot 6$ & - & - & - & $19 / 38$ \\
\hline
\end{tabular}

$\mathrm{H}=$ added hormones.

(1) Storage of fresh semen at room temperature, resuspension for $40 \mathrm{~min}$ in medium with sheep serum.

(2) Incubation of washed spermatozoa for $6 \mathrm{~h}$, at $39^{\circ} \mathrm{C}$, in the presence of sheep serum. 
In sheep (Table 4), pregnancy rates of about $50 \%$ are regularly achieved; moreover a mean litter size of 1.6 can be expected by transfer of 3 in-vitro fertilized zygotes into one recipient (Cognié et al., 1990).

\section{Goat}

Very few data leading to embryonic development have been reported for the goat. Using a short treatment with ionophore A23187 for sperm capacitation, $35.3 \%$ of tubal oocytes were fertilized; after transfer of twelve 2-cell-stage embryos into 5 recipients, only 1 became pregnant, giving birth to 1 offspring (Hanada, 1985). We have applied to the goat the technique previously proposed for the sheep (Crozet et al., 1987). In these conditions $66.6 \%$ and $69.5 \%$ of ovulated and in-vitro matured oocytes were normally fertilized respectively, as attested by the presence of both the male and female pronuclei and remnant of the sperm tail in the ooplasm at $17 \mathrm{~h}$ after insemination.

\section{Conclusions}

It is clear that in-vitro maturation and in-vitro fertilization techniques in ruminants have progressed considerably in recent years and that systems for fertilizing follicular oocytes from cattle, sheep and goats do already exist. However, as judged by the rates of embryonic development, relatively few in-vitro matured and fertilized oocytes are fully competent. Further studies on the mechanisms involved in the final maturation of the gametes are still required to improve the existing in-vitro procedures of oocyte maturation and sperm capacitation and to produce, at low cost, large numbers of competent embryos. Adequate culture systems supporting early development are also required for further applications such as gene transfer and cloning procedures; these should lead to improved viability of the embryos produced and manipulated in vitro, thus avoiding unnecessary transfers to recipient females.

\section{I thank Professor C. Thibault for critical reading of the manuscript.}

\section{References}

Anderson, E, \& Albertini, D.F. (1976) Gap junctions betwen the oocyte and companion follicle cells in the mammalian ovary. I. Cell. Biol. 78, 58-75.

Ball, G.D., Leibfried, M.L., Lenz, R.W., Ax, R.L., Bavister, B.D. \& First, N.L. (1983) Factors affecting successful in vitro fertilization of bovine follicular oocytes Biol, Reprod. 28, 717-725.

Brackett, B.G., Bousquet, D., Boice, M.L., Donawick, W.J., Evans, J.F. \& Dressel, M.A. (1982) Normal development following in vitro fertilization in the cow. Biol. Reprod. 27, 147-158.

Brackett, B.G., Keefer, C.L., Troop, C.G., Donawick, W.J. \& Bennett, K.A. (1984) Bovine twins resulting from in vitro fertilization. Theriogenology 21, 224, abstr.

Cheng, W.T.K. (1985) In vitro fertilization of farm animal oocytes. Ph.D. thesis, University of Cambridge.

Cheng, W.T.K., Moor, R.M. \& Polge, C. (1986) In vitro fertilization of pig and sheep oocytes matured in vivo and in vitro. Theriogenology 25, 146-149.

Cognié, Y., Guérin, Y., Gyader, C., Poulin, N. \& Crozet, N. (1990) In vitro fertilization of sheep oocytes matured in vivo. Theriogenology (in press).

Critser, E.S., Leibfried-Rutledge, M.L., Eyestone, W.H., Northey, D.L. \& First, N.L. (1986) Acquisition of developmental competence during maturation in vitro. Theriogenology 25, 150, abstr.
Crozet, N. (1988) Fine structure of sheep fertilization in vitro. Gamete Res. 19, 291-303.

Crozet, N., Huneau, D., De Smedt, V., Théron, M.C., Szöllösi, D., Torrẻs, S. \& Sévellec, C. (1987) In vitro fertilization with normal development in the sheep. Gamete Res. 16, 159-170.

Cummins, J.M. \& Yanagimachi, R. (1982) Sperm-egg ratios and the site of the acrosome reaction during in vitro fertilization in the hamster. Gamete Res. 5, 239-256.

Dziuk, P.J. (1965) Timing of maturation and fertilization of the sheep egg. Anat. Rec. 153, 211-224.

Fayrer-Hosken, R.A., Younis, A.I., Brackett, B.G., McBride,C.E.,Harper, K.M., Keefer, C.L.\& Cabaniss, C.D. (1989) Laparoscopic oviductal transfer of in vitro matured and in vivo fertilized bovine oocytes. Theriogenology 32, 413-420.

First, N.L. \& Parrish, J.J. (1987) In vitro fertilization in ruminants. J. Reprod. Fert. Suppl. 34, 151-165.

Fukui, Y. \& Ono, H. (1989) Effects of sera, hormones and granulosa cells added to culture medium for in-vitro maturation, fertilization, cleavage and development of bovine oocytes. I. Reprod. Fert. 86, 501-506.

Fukui, Y., Glew, A.M., Gandolfi, F. \& Moor, R.M. (1988) Ram-specific effects on in vitro fertilization and cleavage of sheep oocytes matured in vitro. $J$. Reprod. Ferl. 82, 337-340. 
Goto, K., Kajihara, Y., Koba, M., Kosaka, S., Nakanishi, Y. \& Ogawa, K. (1989) In vitro fertilization and development of in vitro matured bovine follicular oocytes. J. Anim. Sci. 67, 2181-2185.

Hanada, A. (1985) In vitro fertilization in goat. Japan. J. Anim. Reprod 31, 21-26.

Handrow, R.R., First, N.L. \& Parrish, J.J. (1989) Calcium requirement and increased association with bovine sperm during capacitation by heparin. $J_{+}$exp. Zool. 252, 174-182.

Huneau, D. \& Crozet, N. (1989) In vitro fertilization in the sheep: effect of elevated calcium concentration at insemination. Gamete Res. 23, 119-125.

HytteI, P., Callesen, H. \& Greve, T. (1986a) Ultrastructural features of preovulatory oocyte maturation in superovulated cattle. J. Reprod. Fert. 76, 645-656.

Hyttel, P., Xu, K.P., Smith, S. \& Greve, T. (1986b) Ultrastructure of in-vitro oocyte maturaton in cattle. $J$. Reprod. Fert. 78, 615-625.

Hyttel, P., Xu, K.P. \& Greve, T. (1988) Scanning electron microscopy of in vitro fertilization in cattle. Anal. Enbryo. 178, 41-46.

Iritani, A., Utsumi, K., Miyake, M. \& Yamaguchi, Y. (1986) Individual variation in the in vilto fertilizing ability of bull spermatozoa. Dev. Growth, Diff., Suppl. 28, 28-45.

Kruip, T.A.M., Cran, D.G., Van Beneden, T.H. \& Dieleman, S.J. (1983) Structural changes in bovine oocytes during final maturation in vivo. Gamete Res. $8,29-47$.

Langlais, J. \& Roberts, K.D. (1985) A molecular membrane model of sperm capacitation and the acrosome reaction of mammalian spermatozoa. Gamete Res. $12,183-244$.

Langlais, J., Kan, F.W.K., Granger, L., Raymond, L., Bleau, G. \& Roberts, K.D. (1988) Identification of sterol acceptors that stimulate cholesterol efflux from human spermatozoa during in vitro capacitation. Gamete Res. 20, 185-201.

Le Guienne, B., Thibault, C., Chupin, D., Gèrard, M. \& Thibier, M. (1988) Fécondation in vitro chez les mammifères domestiques. Elat actuel et perspectives. Elevage et Insémination 225, 13-22.

Leibfried-Rutledge, M.L., Critser, E.S., Eyestone, W.H., Northey, D.L. \& First, N.L. (1987) Developmental potential of bovine oocytes matured in vitro or in vivo. Biol. Reprod. 36, 376-383.

Leibfried-Rutledge, M.L., Critser, E.S., Parrish, J.J. \& First, N.L. (1989) In vitro maturation and fertilization of bovine oocytes. Theriogenology 31, $61-74$.

Lu, K.H., Gordon, I., Gallagher, M. \& McGovern, H. (1987) Pregnancy established in cattle by transfer of embryos derived from in vitro fertilization of oocytes matured in vitro. Vet. Rec. 121, 259-260.

Marquant-Le Guienne, B. \& Thibault, C. (1987) Fécondation in vitro d'ovocytes bovins matures in vivo ou in vitro. In 25th Coll. Soc, Fr. Et. Fertil., pp. 145-150. Masson, Paris.

Marquant-Le Guienne, B., Gérard, M., Solari, A. \& Thibault, C. (1989) In vitro culture of bovine egg fertilized either in vivo or in vitro. Reprod. Nutr. Dévelop. 29, $559-568$.

Marquant-Le Guienne, B., Humblot, P., Thibier, M. \& Thibault, C. (1990) Evaluation of bull semen fertility by homologous in vitro fertilization tests. Reprod. Nutr. Dévelop. (in press).

Moor, R.M. \& Cran, D.G. (1980) Intercellular coupling in mammalian oocytes. In Development in Mammals. pp, 3-37. Ed. M. H. Johnson. Elsevier/NorthHolland Biomed. Press Amsterdam.

Moor, R.M. \& Crosby, I.M. (1985) Temperature-induced abnormalities in sheep oocytes during maturation. .I. Reprod. Fert. 75, 467-473.

Moor, R.M. \& Gandolfi, F. (1987) Molecular and cellular changes associated with maturation and early development of sheep eggs. $J$. Reprod. Fert., Suppl. 34, 55.69

Moor, R.M. \& Trounson, A.O. (1977) Hormonal and follicular factors affecting maturation of sheep oocytes in vitro and their subsequent developmental capacity. J. Reprod. Fert. 49, 101-109.

Osborn, J.C. \& Moor, R.M. (1983) The role of steroid signals in the maturation of mammalian oocyles. $J$. Sleroid Biochem, 19, 133-137.

Parrish, J.J., Susko-Parrish, J.L. \& First, N.L. (1985) Role of heparin in bovine sperm capacitation. Biol. Reprod. 32 (Suppl, 1), 211, abstr.

Parrish, J.J., Susko-Parrish, J.L. \& First, N.L. (1989) Capacitation of bovine sperm by heparin inhibitory effect of glucose and role of intracellular $\mathrm{pH}$. Biol. Reprod. 41, 683-699.

Pavlok, A., Motlik, J., Kanka, J. \& Fulka, J. (1989) In vitro techniques of bovine oocyte maturation, fertilization and embryo culture resulting in the birth of a calf. Reprod. Nutr. Develop. 29, 611-616.

Piko, L. (1979) Gamete structure and sperm entry in mammals. In Fertilization, vol 2, pp. 325-403. Eds C. B. Metz \& A. Monroy. Academic Press. New York.

Sirard, M.A. \& Lambert, R.D. (1985) In viro fertilization of bovine follicular oocytes obtained by laparoscopy. Biol. Reprod: 33, 487-494.

Sirard, M.A., Lambert, R.D. Ménard, D.P. \& Bedoya, M. (1985) Pregnancies after in-vitro fertilization of cow follicular oocytes, their incubation in rabbit oviduct and their transfer to the cow uterus. J. Reprod. Fort. 75, $551-556$.

Sirard, M.A., Parrish, J.J., Ware, C.B., LeibfriedRutledge, M.L. \& First, N.L. (1988) The culture of bovine oocytes to obtain developmentally competent embryos. Biol. Reprod. 39, 546-552.

Staigmiller, R.B. \& Moor, R.M. (1984) Effect of follicle cells on the maturation and developmental competence of ovine oocytes matured outside the follicle. Gamete Res. 9, 221-229.

Szöllösi, D., Gérard, M., Ménézo, Y. \& Thỉbault, C. (1978) Permeability of ovarian follicle: corona cell oocyte relationship in mammals. Anmls Biol. anim. Biochim. Biophys. 18, 51 I-521.

Szöllösi, D., De Smedt, V., Crozet, N. \& Brender, C. (1988) In vitro maturation of sheep ovarian oocytes. Reprod. Nutr. Dévelop. 28, 1047-1080.

Thibault, C. (1972) Final stages of oocyte maturation. In Oogenesis, pp. 397-411. Eds J. D. Biggers \& A. W. Schuetz. University Park Press, Baltimore.

Thibault, C. \& Gérard, M. (1970) Facteur cytoplasmique nécessaire à la formation du pronucleus mảle dans l'ovocyte de Lapine. C. r. hebd. Sèanc. Acud. Sci., Paris 270, 2025-2026. 
Thibault, C., Szöllösi, D. \& Gérard, M. (1987) Mammalian oocyte maturation. Reprod. Nutr. Dévelop. 27, 865-896.

Warnes, G.M., Moor, R.M. \& Johnson, M.H. (1977) Changes in protein synthesis during maturation of sheep oocytes in vivo and in vitro. I. Reprod. Fert. 49 , $331-335$
Xu, K.P., Greve, T., Callesen, H. \& Hyttel, P. (1987) Pregnancy resulting from cattle oocytes matured and fertilized in vitro. J. Reprod. Fert, 81, 501-504.

Younis, A.I., Brackett, B.G. \& Fayrer-Hosken, R.A. (1989) Influence of serum and hormones on bovine oocyte maturation and fertilization in vitro. Gamete Res. 23, 189-201. 